Article

\title{
Quality of Institutions, Technological Progress, and Pollution Havens in Latin America. An Analysis of the Environmental Kuznets Curve Hypothesis
}

\author{
José M. Cansino ${ }^{1,2, *(\mathbb{D})}$, Rocio Román-Collado ${ }^{1,2}$ and Juan C. Molina ${ }^{1}$ \\ 1 Departamento de Análisis Económico y Economía Política, Universidad de Sevilla, Sevilla 410818, Spain \\ 2 Universidad Autónoma de Chile, Santiago 7500912, Chile \\ * Correspondence: jmcansino@us.es; Tel.: +34 954557528
}

Received: 16 May 2019; Accepted: 2 July 2019; Published: 6 July 2019

check for updates

\begin{abstract}
A set of 17-year panel data (1996-2013) across a representative sample from eighteen Latin American countries is used to respond four research questions: Did Latin American Greenhouse Gas (GHG) emissions prove the Environmental Kuznets Curve (EKC) hypothesis? Did the quality of institutions play a compensating role for income on environmental stress? Did technological progress help decouple income from environmental stress? Has the Pollution Haven Hypothesis (PHH) been proven? In order to answer the research questions, the paper expands the traditional EKC approach by including an exclusive quality analysis of institutions, technological progress, and $\mathrm{PHH}$ as part of the model. This innovation is developed considering the most recent literature about EKC as a starting point. Major findings show that the relationship between income and GHG emissions is adjusted to the traditional EKC hypothesis for the analyzed period. They also show that the quality of institutions and technological progress improve environmental sustainability. However, the variables, Foreign Direct Investment and International Trade, provide a negative answer to the fourth question. The main methodological contribution of this paper is to use a threefold extended classic EKC model to conduct the feasible generalized least squares method. The paper also contributes to the growing body of PHH literature.
\end{abstract}

Keywords: environmental Kuznets curves; quality of institutions; $\mathrm{CO}_{2}$ emissions; technological progress; pollution haven hypothesis

\section{Introduction}

Since the release of seminal papers by [1] and [2], there has been prolific development of the so-called Environmental Kuznets Curve (EKC) by analogy with the income inequality postulated by Kuznets [3]. In December 1954, at the sixty-seventh annual meeting of the American Economic Association, Simon Kuznets suggested that as per capita income increases, income inequality increases at first, but then after reaching a particular turning point, it begins to decrease [4].

The EKC hypothesis assumes an inverted U shape curve showing a non-linear relationship between incomes or economic growth and environmental stress, which is usually measured as pollutant gas emissions into the atmosphere (i.e., Greenhouse gases). The basic idea upon which this assumption is built states that a transition from an industrialized to a tertiary economy decreases environmental stress. This would allow meeting the needs of the present without compromising the ability of future generations to meet their needs as the sustainability establishes. Together with this, the traditional EKC hypothesis also highlights the role of improving technological progress by replacing high energy intensive technologies with lower ones.

An EKC reveals how a specified measurement of environmental quality changes as the welfare of a country changes. The common point of research focused on the EKC hypothesis is that the 
environmental quality deteriorates at the early stages of economic growth but improves at the later ones with higher levels of income [5]. Since the early 1990s, the EKC concept has led many researchers to assume that each economy should focus on its own growth, and any environmental problems will be solved by the process of economic growth without any environmental protection-oriented measures [6]. However, some evidence shows that developing countries are addressing environmental issues; sometimes, they address them by adopting developed country standards with a short time lag and sometimes performing better than some high-income countries. Evidence also shows that the EKC results have a very flimsy statistical foundation [7].

From the perspective of developing countries, the EKC hypothesis offers advice on a necessary first income growth stage that damages environmental quality before decoupling them. Reaching the maximum EKC point sooner becomes a crucial point for developing economies.

Including technological progress in EKC research has been less frequent than only exploring the relationship between income or economic growth and environmental stress. When technological progress is included in the model, research improves its interest, particularly if it is oriented towards meeting a sustainable economic growth pathway. Designing the right roadmap to reduce the EKC curve, $[8,9]$ proved that a more sustainable economic growth (a softer slope of EKC) is possible, thanks to government measures that are oriented towards protecting the environment.

The basic idea upon which this assumption is built states that a transition from an industrialized to a tertiary economy decreases environmental stress. This would allow meeting the needs of the present without compromising the ability of future generations to meet their needs as the sustainability establishes. Here, institutions are defined in the sense of [10] as the humanly devised constraints that structure political, economic, and social interaction. Institutions-in the sense of North-consist of both informal constraints and formal rules. The author conceived informal constraints as sanctions, taboos, customs, traditions, codes of conduct, while formal rules were constitutions, laws, and property rights. Together with this, the term decoupling is used in environmental studies to characterize the link between economic activity and environmental degradation, or using the terminology of the [11], the link between "economic goods" and "environmental bads". Decoupling would be characterized as a disruption in the growth rate of environmental pressure (e.g., $\mathrm{CO}_{2}$ emissions) and economic activity over a given period [12]. However, there is some controversy regarding the term. [13] prefers to move away from the concept of 'decoupling' mentioned above, which is often used to refer to the situation where resources impact on the decline relative to GDP growth. The author pointed out that the term decoupling has been used as a key political element to bridge the contentious debate on continuous economic growth and its negative impact on the environment. Finally, the author argued that the term 'decoupling' is misleading and that it should be understood as no coupling because it is impossible to have economic growth without affecting the environment.

Based on the role played by institutions, recent literature has attempted to include institution quality as a novelty in the EKC approach [14-19].

Finally, in terms of a legal framework as a part of institutions, global governance in the battle against Climate Change has marked many countries (mainly, the so-called Annex I countries in Kyoto Protocol jargon) as commitments oriented towards mitigating their Greenhouse Gas emission levels. Advances in global Climate Change governance coincided in time with intensive offshoring and outsourcing processes. Many scholars explored whether part of the international trade, offshoring, and outsourcing processes was due to movements of high pollutant industries seeking refuge in countries with a low standard of legal environmental protection framework. This is known as the pollution haven hypothesis and needs to be considered as a part of new EKC research. The pollution haven hypothesis (also known as pollution haven effect) posits that jurisdictions with weak environmental regulations-named 'pollution havens'-would attract polluting industries relocating from more stringent locales. The basic idea is that environmental regulations raise the cost of key inputs to goods with pollution-intensive production and that they reduce jurisdictions' comparative advantage in manufacturing them. The Pollution Haven hypothesis claims that due to international trade and 
foreign direct investment (FDI), developing countries appear to be the pollution haven for developed countries [20]. The Heckscher-Ohlin model [21] provides the theoretical foundations by showing that regions will export goods that use locally abundant factors as inputs. In the context of a more integrated world, falling trade barriers imply that the role environmental restrictions play in shaping a country's comparative advantage is greater than before. This has led to fears that pollutant industries will relocate to developing regions where environmental barriers may be less stringent [22].

The pollution haven hypothesis- $\mathrm{PHH}$ - establishes that multinational corporations engaging in highly polluting activities move to the developing countries with weaker environmental standards where the cost of complying with environmental regulations is lower [23]. Such situations are extremely interesting for developing countries because they usually have weaker legal requirements when it comes to protecting the environment. However, the results regarding PHH remain inconclusive as [20] remarked. These authors wrote that, despite the fact that the PHH has been studied theoretically and empirically all over the world (being examined with different specifications, functional forms, variables, estimation methods, and datasets), the results are mixed at best. Thus, scientific contributions to this topic are welcome.

The main methodological contribution of this paper is to expand the traditional EKC approach by including an exclusive quality analysis of institutions, technological progress, and $\mathrm{PHH}$ as part of the model. This innovation is developed by taking recent literature modeling EKC as a starting point $[2,5,8,24-28]$. This paper also contributes to the growing body of $\mathrm{PHH}$ literature.

Literature shows that there is a knowledge gap to be filled regarding EKC's evidence. Expanding the classical approach by including quality of institutions, technological progress, and PHH could help to reduce this gap. In this study, a set of 17-year panel data (1996-2013) across a broad sample of eighteen Latin American countries has been used. The end of this period was due to no longer availability of the quality institutions data. By focusing on this sample, the aim of this paper is to respond to the following research questions:

- Did Latin American Greenhouse Gas emissions prove the EKC hypothesis?

- Did the quality of institutions play a compensating role for income on environmental stress?

- Did technological progress act in line with the quality of institutions to help decouple income from environmental stress?

- Has the PHH been proven for the selected sample during the period under consideration?

The main utility of the results is related to the fulfillment of mitigation commitments of Greenhouse Gas (GHG) emissions reached at the U.N. Framework Convention on Climate Change (UNFCCC) Conference of the Parties (COP21) in Paris in December 2015, also known as Paris Agreement. Because all the countries in the sample are signatories to this agreement-although they do not appear in Annex 1-they have assumed coded commitments to reduce their GHG emissions in the coming years. These commitments are detailed in the Intended Nationally Determined Contributions (INDCs) sent by each country before the signing of the Agreement and subsequently ratified. Given that the results shed light on the relationships between the analyzed variables and environmental stress, as measured by GHG emissions, it is possible to identify the efforts that must be made in order to improve the quality of institutions, the Research+Develepment policy, the consumption patterns of the population, energy consumption, the energy matrix, international trade, or possible controls on the orientation of the FDI.

This paper is organized as follows: after the Introduction, Section 1 details the methodology used by emphasizing the new aspects developed. Section 2 describes the dataset used. Adjusted models and empirical results are shown in Section 3 (empirical models in Section 3.1 and findings in Section 3.2). Finally, Section 4 concludes and also offers a number of political recommendations. 


\section{Materials and Methods}

\subsection{Methods}

In response to the research questions posed, the EKC classic model has been used as the starting point to test the relationship between environmental degradation or environmental stress and income growth. The main contribution of this paper is the way of expanding the EKC classic model in a sequentially way summarized in a diagram at the end of this sub Section. This paper uses a panel data methodology. Cross-sectional and country-specific data for the period from 1996 to 2013 is pooled for a sample of eighteen Latin American countries. The specification model given by Equation (1) is based on $[2,8,24-28]$.

$$
Y_{i t}=\beta_{1} X_{i t}+\beta_{2} X_{i t}^{2}+\beta_{3} X_{i t}^{3}+\beta_{4} Z_{i t}+\mu_{i}+\delta_{t}+\varepsilon_{i t}
$$

where it refers to country $i(\mathrm{i}=\mathrm{i}, \ldots, \mathrm{N})$ in time $t(\mathrm{t}=1, \ldots, \mathrm{T}), \mathrm{Y}$ is a variable representing environmental stress or degradation measured with the pollutant gas emissions into the atmosphere. $X$ measures the income level for each country. $Z$ is a vector that includes control variables usually considered in the literature, while $\mu_{i}$ measures the unobserved fixed effect for each country. $\delta_{t}$ captures the specific time effect, while $\varepsilon$ captures the stochastic error. $X$ coefficients allow the form of the curve and to test the EKC hypothesis to be known. The cubic term in Equation (1) allows proving whether the trend reverses after a decrease in environmental stress. Various forms for EKC are summarized in Table 1 [27]. The EKC hypothesis is proven when represented as an inverted U-shaped curve. The cubic term in Equation (1) tests whether EKC takes an $\mathrm{N}$ form when income levels increase.

Table 1. Different types of Environmental Kuznets Curve (EKC).

\begin{tabular}{cccc}
\hline$\beta_{1}>0$ & $\beta_{2}=0$ & $\beta_{3}=0$ & Monotonically increasing \\
\hline$\beta_{1}<0$ & $\beta_{2}=0$ & $\beta_{3}=0$ & Monotonically decreasing \\
\hline$\beta_{1}>0$ & $\beta_{2}<0$ & $\beta_{3}=0$ & Inverted U shape. The EKC is valid. \\
\hline$\beta_{1}<0$ & $\beta_{2}>0$ & $\beta_{3}=0$ & U Shape \\
\hline$\beta_{1}>0$ & $\beta_{2}<0$ & $\beta_{3}>0$ & $\mathrm{~N}$ form \\
\hline$\beta_{1}<0$ & $\beta_{2}>0$ & $\beta_{3}<0$ & Inverted N shape \\
\hline \multicolumn{4}{c}{ Source: [27]. }
\end{tabular}

Environmental degradation or stress for total per capita Greenhouse Gas emissions is measured in kt of $\mathrm{CO}_{2}$ equivalent (Greenhouse Gases pc). This variable is commonly used in specialized literature, although energy consumption is also used to proxy environmental stress [28-30]. Carbon dioxide emissions from fossil fuel combustion are an important driver of Global Climate Change. Increased energy demand stimulates economic growth, but energy use also drives Greenhouse Gas emissions [31]. Deforestation is also used to proxy environmental stress but less than Greenhouse Gases and energy consumption [15]. Income level is measured in per capita GDP 2011 US \$ at Purchase Price Parity. To soften outliers and the direct elasticities values obtained, natural logarithms were taken. Equation (1) is re-written as,

$$
\ln G H G p c_{i t}=\beta_{1} \ln G D P p c_{i t}+\beta_{2} \ln G D P p c_{i t}^{2}+\beta_{3} \ln G D P p c_{i t}^{3}+\beta_{4} Z_{i t}+\mu_{i}+\delta_{t}+\varepsilon_{i t}
$$

Considering that this study is not limited to only proving the EKC hypothesis but also tests the role played by the quality of institutions and technological progress on environmental stress, two variables measuring them (Institutions, INST and technological progress, TECH) were included in the classic EKC model. It is expected that both the quality of institutions and technological progress act as inhibitors of Greenhouse Gas emissions. Additionally, the expanded model includes the crossed product of $($ GDP per capita $\times$ INST) and $($ GDP per capita $\times$ TECH) to capture the interaction effect 
of these new variables on Greenhouse Gas emissions. This methodological approach goes in line with $[15,18,19,32-36]$. Equation (3) shows the extended EKC model:

$$
\begin{aligned}
& \ln G H G p c_{i t}=\beta_{1} \ln G D P p c_{i t}+\beta_{2} \ln G D P p c_{i t}{ }^{2}+\beta_{3} \ln G D P p c_{i t}{ }^{3}+\beta_{4} I N S T_{i t} \\
& +\beta_{5} T_{E C H}+\beta_{6}\left(\ln G D P p c_{i t} \times I N S T_{i t}\right) \\
& +\beta_{7}\left(\ln G D P p c_{i t} \times I N S T_{i t}\right)^{2}+\beta_{8}\left(\ln G D P p c_{i t} \times I N S T_{i t}\right)^{3} \\
& +\beta_{9}\left(\ln G D P p c_{i t} \times T E C H_{i t}\right)+\beta_{10}\left(\ln G D P p c_{i t} \times T E C H_{i t}\right)^{2} \\
& +\beta_{11}\left(\ln G D P p c_{i t} \times T E C H_{i t}\right)^{3}+\beta_{12} Z_{i t}+\mu_{i}+\delta_{t}+\varepsilon_{i t}
\end{aligned}
$$

To measure the quality of institutions, the World Bank offers useful statistical information for a broad list of countries referenced for almost the past two decades [37]. This database uses six different indicators to measure the quality of institutions for the countries considered. These indicators are Political Stability and Absence of Violence/Terrorism (PSAVT), Control of Corruption (CC), Government Effectiveness (GE), Regulatory Quality (RQ), Rule of Law (RL), and Voice and Accountability (VA). Recent studies using this database are [33] and [35]. An in-depth methodological revision of these indicators may be found at [38]. This study uses all six indicators in search of better robustness of results.

Following definitions given by the World Bank, Political Stability and Absence of Violence/Terrorism (PSAVT) captures perceptions for the likelihood of political instability and/or politically motivated violence. Control of Corruption (CC) indicates the perceptions regarding forms of corruption, as well as the "capture" of the state by elites and private interests. Government Effectiveness (GE) measures perceptions from users of the quality of public goods and services and if civil servants are independent of political pressures or not. GE also captures the quality of policy formulation and implementation and the credibility of government commitment to such policies. Regulatory Quality (RQ) shows the perceptions of government ability to formulate and implement sound policies and regulations that permit and promote private sector development. Rule of Law (RL) puts the focus on the perceptions that agents have about abiding by the rules of society. Special interest is paid in the quality of contracts enforcement, property rights, the police, and the courts' decisions. RL also provides information on the likelihood of crime and violence. Finally, Voice and Accountability (VA) covers the perceptions of the extent to which a country's citizens are able to participate in selecting their government, including freedom of expression, association, and free media.

An estimate gives the country's score on the aggregate indicator, in units of a standard normal distribution. Values range from approximately -2.5 to 2.5. Higher values in indicators mean a higher quality of institutions. It is expected that an increase in the value of any one of the indicators provokes a reduction in Greenhouse Gas emissions. This goes in line with [15] in the sense that institutions oriented to secure property rights and better environmental policies for moving the economic system towards a right growth path could reduce the maximum point of an environmental Kuznets curve (EKC) relationship between income and environmental stress.

Technological progress (TECH) in Equation (3) is measured through high-technology product exports as a percentage of total manufactured product exports. This allows examining the extent to which the EKC inverted U relationship can be explained by trade and the displacement of pollutant industries between the samples of considered countries [39]. It is also expected that technological progress acts as an inhibitor or a compensating factor of Greenhouse Gas emissions into the atmosphere. 
Following [32], the extended EKC model used in this study also includes control variables. The literature shows that these variables have been largely tested. They are based on the IPAT equation and the Kaya identity [40-44]. The first control variable used was the natural logarithm of the total population $(\operatorname{lnP})$. Available literature shows that a population increase acts as a driver of Greenhouse Gas emissions. A second control variable is total energy consumption (EC), measured, in turn, as miles of barrel-oil-equivalent per million of GDP (2010 US \$). It is expected that an increase in EC will drive Greenhouse Gas emissions. The third control variable advises the matrix of energy resources (ERM), defined as the ratio between renewable energy sources on the total energy resources used. Increased use of renewable energy sources (which means a higher ERM value) might act as an inhibitor of Greenhouse Gas emissions.

A last extension of the classic EKC model allows the PHH to be tested. This extension is deployed by including international trade and direct foreign investment in the classic model. Part of the literature focuses on the impact of international trade on pollutant emissions, mainly in emerging economies [45-48]. To assess the impact of international trade (named as TRADE in the model), the authors of this paper have used commodities trade as a percentage of GDP. Together with the role played by international trade, recent outsourcing and offshoring processes would stress the negative impact of international trade on Greenhouse Gas emissions. The basic idea of the PHH implies that Foreign Direct Investment (FDI) will flow to countries with less stringent environmental protection standards and hence, successfully result in depleting the environment. Following the definition of the OEDC for FDI, this is conceived as a category of cross-border investment made by a resident in one country (the direct investor) to establish a lasting interest in an enterprise (the affiliate enterprise) that is resident in a country other than that of the direct investor. It is expected that FDI flows to countries with low quality of environmental protection for institutions [19,49-55]. There have been several debates. Recent literature on the consequences of FDI for less-developed countries states that it may contribute to different forms of environmental degradation in these countries (e.g., [56-60]). From a panel dataset of 187 countries, [61] found that embodied $\mathrm{CO}_{2}$ emissions in the international trade had been on the rise in developed and developing countries during the period 1970 to 2011. Using a Multiregional Input-Output Model (MRIO), they claimed that $72 \%$ of embodied flows of $\mathrm{CO}_{2}$ were being generated from the so-called non-Annex I countries signatory of Kyoto's protocol. This indicated the existence of $\mathrm{PHH}$ type trade flows.

To test PHH, FDI is measured as direct foreign investment and net inflows ( $\%$ of GDP). Based on the previously stated arguments, it is possible to rewrite Equation (3) to formulate a more extended version of the classic EKC model as Equation (4) does:

$$
\begin{aligned}
& \ln G H G p c_{i t}=\beta_{1} \ln G D P p c_{i t}+\beta_{2} \ln G D P p c_{i t}{ }^{2}+\beta_{3} \ln G D P p c_{i t}{ }^{3}+\beta_{4} I N S T_{i t} \\
& +\beta_{5} T_{E C H}+\beta_{6}\left(\ln G D P p c_{i t} \times I N S T_{i t}\right) \\
& +\beta_{7}\left(\ln G D P p c_{i t} \times I N S T_{i t}\right)^{2}+\beta_{8}\left(\operatorname{lnGDPpc_{it}} \times I N S T_{i t}\right)^{3} \\
& +\beta_{9}\left(\ln G D P p c_{i t} \times T E C H_{i t}\right)+\beta_{10}\left(\ln G D P p c_{i t} \times T E C H_{i t}\right)^{2} \\
& +\beta_{11}\left(\ln G D P p c_{i t} \times T E C H_{i t}\right)^{3}+\beta_{12} \ln P_{i t}+\beta_{13} E C_{i t} \\
& +\beta_{14} E R M_{i t}+\beta_{15} T R A D E_{i t}+\beta_{16} F D I+\mu_{i}+\delta_{t}+\varepsilon_{i t}
\end{aligned}
$$

The following diagram (Figure 1) summarizes the main sequence of methodological steps described in Equations (1)-(4). 


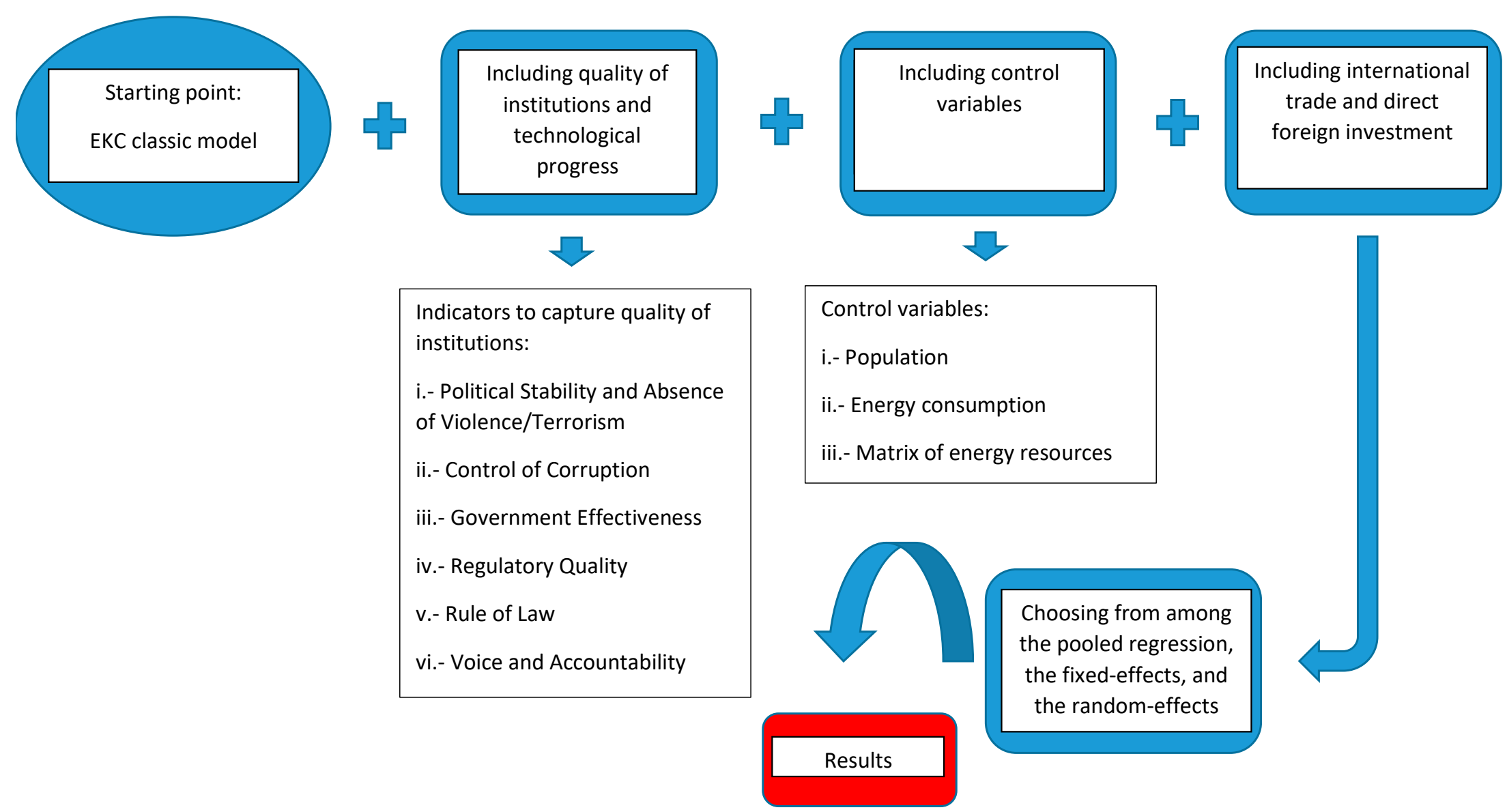

Figure 1. The Main sequence of methodological steps. 


\subsection{Data}

Panel data containing cross-sectional country-specific annual data over a 17-year period (1996-2013) for eighteen Latin American countries has been used. Argentina, Bolivia, Brazil, Chile, Colombia, Dominican Republic, Ecuador, Guatemala, Honduras, Haiti, Mexico, Nicaragua, Panama, Peru, Paraguay, El Salvador, Uruguay, and Venezuela made up the sample group. The sample of countries was based on the availability of data, as was the period to be considered. Data for Greenhouse Gas emissions, GDPpc, TECH, P, TRADE, and FDI variables were taken from the World Development Indicator database (WDI). Data for quality of institution indicators were taken from The Worldwide Governance Indicators (WGI) project. Data for EC and energy sources were taken from the database named CEPALSTATS. Indicators measuring the quality of institutions were built by WGI upon the specific local/national characteristics and regulations. Besides, the control variables (mainly population and energy resource mix) also take into account specific local/national characteristics of countries included in the sample. The supplementary materials include an excel file with full data used in this research.

Table 2 offers a detailed description of the variables included in the extended EKC model with this same Table showing the expected sign of coefficients. It is expected that the sign of the variables $\ln$ (GDPpc), $\ln \left(G D P p c^{2}\right)$, and $\ln \left(G D P p c^{3}\right)$ fulfill some of the standard models of EKC shown in Table 1. In correspondence to what has been explained in Section 2, it is expected that an increase in the variables $\ln \left(G D P p c^{2}\right), P S A V T, C C, G E, R Q, R L, V A, T E C H, \ln \left(G D P p c^{2}\right) x P S A V T / C C / G E / R Q / R L / V A$, $\ln \left(G D P p c^{2}\right) x T E C H$, EE (Renewable energy sources on total energy use) reduce deeply the level of emissions, while an increase in the variables $\ln (\mathrm{GDPpc}), \ln (\mathrm{GDPpc}) \times \mathrm{PSAVT} / \mathrm{CC} / \mathrm{GE} / \mathrm{RQ} / \mathrm{RL} / \mathrm{VA}$, $\ln (\mathrm{GDPpc}) \times \mathrm{TECH}, \mathrm{Ln}(\mathrm{P}), \mathrm{EC}, \mathrm{TRADE}, \mathrm{FDI}$ increase considerably the emissions level.

Table 2. Details of variables.

\begin{tabular}{|c|c|c|c|c|}
\hline Variable & Explanation & Unit & Source & $\begin{array}{l}\text { Expected } \\
\text { Sign }\end{array}$ \\
\hline $\ln (G H G p c)$ & Total greenhouse gas emission & $\begin{array}{c}\ln \left(\mathrm{kt} \text { of } \mathrm{CO}_{2}\right. \\
\text { equivalent })\end{array}$ & WDI & \\
\hline $\ln (G D P p c)$ & $\begin{array}{l}\text { GDP per capita, PPP (current } \\
\text { international \$) }\end{array}$ & $\ln (1000$ US\$ 2011) & WDI & Positive \\
\hline $\ln \left(G D P p c^{2}\right)$ & GDP per capita square & & WDI & Negative \\
\hline $\ln \left(G D P p c^{3}\right)$ & GDP per capita cube & & WDI & \pm \\
\hline PSAVT & $\begin{array}{l}\text { Political Stability and Absence } \\
\text { of Violence/Terrorism (PSAVT) }\end{array}$ & $\begin{array}{l}\text { Values between } \\
-2.5 \text { and } 2.5\end{array}$ & WGI & Negative \\
\hline$C C$ & Control of Corruption (CC) & $\begin{array}{l}\text { Values between } \\
-2.5 \text { and } 2.5\end{array}$ & WGI & Negative \\
\hline$G E$ & Government Effectiveness (GE) & $\begin{array}{l}\text { Values between } \\
-2.5 \text { and } 2.5\end{array}$ & WGI & Negative \\
\hline$R Q$ & Regulatory Quality (RQ) & $\begin{array}{l}\text { Values between } \\
-2.5 \text { and } 2.5\end{array}$ & WGI & Negative \\
\hline$R L$ & Rule of Law (RL) & $\begin{array}{l}\text { Values between } \\
-2.5 \text { and } 2.5\end{array}$ & WGI & Negative \\
\hline$V A$ & Voice and Accountability (VA) & $\begin{array}{l}\text { Values between } \\
-2.5 \text { and } 2.5\end{array}$ & WGI & Negative \\
\hline TECH & High-technology exports & $\begin{array}{l}\text { Percentage of } \\
\text { manufactured } \\
\text { exports }\end{array}$ & WGI & Negative \\
\hline $\begin{array}{c}\ln (G D P p c) \times \\
P S A V T / C C / G E / R Q / R L / V A\end{array}$ & Terms of interaction & & & Positive \\
\hline
\end{tabular}


Table 2. Cont.

\begin{tabular}{|c|c|c|c|c|}
\hline Variable & Explanation & Unit & Source & $\begin{array}{l}\text { Expected } \\
\text { Sign }\end{array}$ \\
\hline $\begin{array}{c}\ln \left(G D P p c^{2}\right) \times \\
P S A V T / C C / G E / R Q / R L / V A\end{array}$ & Terms of interaction & & & Negative \\
\hline $\begin{array}{c}\ln \left(G D P p c^{3}\right) \times \\
P S A V T / C C / G E / R Q / R L / V A\end{array}$ & Terms of interaction & & & \pm \\
\hline $\ln (G D P p c) \times T E C H$ & Terms of interaction & & & Positive \\
\hline $\ln \left(G D P p c^{2}\right) \times E C H$ & Terms of interaction & & & Negative \\
\hline $\ln \left(G D P p c^{3}\right) \times T E C H$ & Terms of interaction & & & \pm \\
\hline $\operatorname{Ln}(P)$ & Total population & $\ln$ (units) & WDI & Positive \\
\hline$E C$ & $\begin{array}{l}\text { Energy consumption (EC) per } \\
\text { million dollars of GDP at } \\
\text { constant } 2010 \text { prices }\end{array}$ & $\begin{array}{c}\text { Thousands of } \\
\text { barrels of oil } \\
\text { equivalent }\end{array}$ & CEPAL & Positive. \\
\hline$E E$ & $\begin{array}{l}\text { Renewable energy sources on } \\
\text { total energy use }\end{array}$ & Proportion & CEPAL & Negative \\
\hline TRADE & Merchandise trade (\% of GDP) & Percentage & WDI & Positive \\
\hline$F D I$ & $\begin{array}{l}\text { Foreign direct investment, net } \\
\text { inflows }\end{array}$ & Percentage & WDI & Positive \\
\hline
\end{tabular}

The dataset is complete for almost all variables considered in the analysis until 2013 with the exception of The Worldwide Governance Indicators and the dependent variable GHGpc. However, the missing values of these variables are limited. The WGI database, consisting of the variables PSAVT, CC, GE, RQ, RL, and VA, is 82\% complete. Missing values appear for some countries in 1997, 1999, and 2001. The dataset for the dependent variable GHGpc is $94 \%$ complete with only missing data for some countries in 2013. The linear interpolation method was used to estimate the missing values. Table 3 provides descriptive statistics, providing information about the nature and distribution of the data. Descriptive statistics help to avoid bias in the econometric estimation by identifying potential outliers through the indicators mean, standard deviance (Std. Dev.), minimum (min), and maximum (max). The overall values refer to the whole sample. The between values refer to the standard deviation of the averages of each individual country as well as to the minimum and maximum of the averages of each individual country. The within values are referred to the standard deviation, minimum, and maximum of the variation of a country's values from its average over time. It can be observed that there is a greater variety among the 'between' values than the 'within' values.

Table 3. Descriptive Statistics.

\begin{tabular}{ccccccc}
\hline Variable & & Mean & Std. Dev. & Min & Max & Obs \\
\hline $\ln ($ GHGpc) & Overall & -5.330286 & 0.7015173 & -6.432259 & -2.786832 & $\mathrm{~N}=324$ \\
& Between & & 0.6852661 & -6.265535 & -3.959671 & $\mathrm{n}=18$ \\
& Within & & 0.2173756 & -6.287268 & -4.157447 & $\mathrm{~T}=18$ \\
\hline $\ln (\mathrm{GDPpc})$ & Overall & \multirow{2}{*}{8.972472} & 0.5152072 & 7.738997 & 10.02322 & $\mathrm{~N}=324$ \\
& Between & & 0.4667575 & 8.093602 & 9.559566 & $\mathrm{n}=18$ \\
& Within & & 0.2429863 & 8.480332 & 9.562592 & $\mathrm{~T}=18$ \\
\hline \multirow{2}{*}{ PSAVT } & Overall & -0.3426055 & 0.6530893 & -2.3857 & 0.9973063 & $\mathrm{~N}=324$ \\
& Between & & 0.6386092 & -1.749541 & 0.7633462 & $\mathrm{n}=18$ \\
& Within & & 0.2004201 & -1.062043 & 0.1544409 & $\mathrm{~T}=18$ \\
\hline CC & Overall & -0.303594 & 0.6779242 & -1.444359 & 1.572951 & $\mathrm{~N}=324$ \\
& Between & & 0.6782205 & -1.124076 & 1.444894 & $\mathrm{n}=18$ \\
& Within & & 0.1542978 & -0.7346453 & 0.2069996 & $\mathrm{~T}=18$ \\
\hline
\end{tabular}


Table 3. Cont.

\begin{tabular}{|c|c|c|c|c|c|c|}
\hline Variable & & Mean & Std. Dev. & Min & Max & Obs \\
\hline \multirow[t]{3}{*}{ GE } & Overall & -0.2242938 & 0.5613994 & -1.195942 & 1.285714 & $\mathrm{~N}=324$ \\
\hline & Between & & 0.5595473 & -0.9695299 & 1.206711 & $\mathrm{n}=18$ \\
\hline & Within & & 0.1362154 & -0.627603 & 0.2027976 & $\mathrm{~T}=18$ \\
\hline \multirow[t]{3}{*}{$\mathrm{RQ}$} & Overall & 0.0139563 & 0.6209773 & -1.624753 & 1.64474 & $\mathrm{~N}=324$ \\
\hline & Between & & 0.5780686 & -0.9828321 & 1.473358 & n 18 \\
\hline & Within & & 0.2627492 & -0.627965 & 1.0229 & $\mathrm{~T}=18$ \\
\hline \multirow[t]{3}{*}{ RL } & Overall & -0.4673229 & 0.6504213 & -1.812253 & 1.374353 & $\mathrm{~N}=324$ \\
\hline & Between & & 0.6450485 & -1.288491 & 1.248214 & $\mathrm{n}=18$ \\
\hline & Within & & 0.1698815 & -0.9910853 & 0.0704554 & $\mathrm{~T}=18$ \\
\hline \multirow[t]{3}{*}{ VA } & Overall & 0.1005125 & 0.501417 & -0.9618688 & 1.243549 & $\mathrm{~N}=324$ \\
\hline & Between & & 0.4887367 & -0.5652662 & 1.018083 & $\mathrm{n}=18$ \\
\hline & Within & & 0.1585155 & -0.3783807 & 0.6263118 & $\mathrm{~T}=18$ \\
\hline \multirow[t]{3}{*}{$\mathrm{TECH}$} & Overall & 8.431279 & 10.28533 & 0.0013268 & 63.40368 & $\mathrm{~N}=324$ \\
\hline & Between & & 9.000392 & 2.104588 & 39.17926 & $\mathrm{n}=18$ \\
\hline & Within & & 5.389303 & -26.54516 & 46.34956 & $\mathrm{~T}=18$ \\
\hline \multirow[t]{3}{*}{$\mathrm{EC}$} & Overall & 1.132556 & 0.4396158 & 0.5684226 & 2.250259 & $\mathrm{~N}=324$ \\
\hline & Between & & 0.4349587 & 0.6260214 & 1.945453 & $\mathrm{n}=18$ \\
\hline & Within & & 0.1184493 & 0.7483654 & 1.454636 & $\mathrm{~T}=18$ \\
\hline \multirow[t]{3}{*}{$\mathrm{EE}$} & Overall & 32.94112 & 19.09179 & 7.208523 & 76.0548 & $\mathrm{~N}=324$ \\
\hline & Between & & 19.16819 & 8.317099 & 72.74032 & $\mathrm{n}=18$ \\
\hline & Within & & 4.05148 & 20.42738 & 56.42065 & $\mathrm{~T}=18$ \\
\hline \multirow[t]{3}{*}{$\ln (\mathrm{P})$} & Overall & 16.43776 & 1.136914 & 14.84329 & 19.1349 & $\mathrm{~N}=324$ \\
\hline & Between & & 1.165363 & 15.00335 & 19.04008 & $\mathrm{n}=18$ \\
\hline & Within & & 0.0773366 & 16.23665 & 16.62771 & $\mathrm{~T}=18$ \\
\hline \multirow[t]{3}{*}{ FDI } & Overall & 3.712267 & 2.771048 & -5.007236 & 16.22949 & $\mathrm{~N}=324$ \\
\hline & Between & & 1.969363 & 0.6969128 & 8.315166 & $\mathrm{n}=18$ \\
\hline & Within & & 2.00111 & -3.94247 & 11.62659 & $\mathrm{~T}=18$ \\
\hline \multirow[t]{3}{*}{ TRADE } & Overall & 52.11963 & 23.94042 & 12.29259 & 120.7539 & $\mathrm{~N}=324$ \\
\hline & Between & & 20.743 & 18.93556 & 108.3071 & $\mathrm{n}=18$ \\
\hline & Within & & 12.86537 & 14.95344 & 93.1011 & $\mathrm{~T}=18$ \\
\hline
\end{tabular}

\section{Results}

\subsection{Model Estimation}

Table 4 provides the correlation matrix, showing the linear relationship between the pairs of the variables. Values that come closer to one or minus one will show stronger correlations. The variables InGDP, EE, InP, and TRADE show the biggest correlation with the dependent variable. Most of the coefficients show values under $50 \%$; stronger correlations appear between indicators measuring the quality of institutions. This recommends not including them together in the same model. 
Table 4. Correlation matrix.

\begin{tabular}{|c|c|c|c|c|c|c|c|c|c|c|c|c|c|c|}
\hline & (1) & (2) & (3) & (4) & (5) & (6) & (7) & (8) & (9) & (10) & (11) & (12) & (13) & (14) \\
\hline (1) $\ln (\mathrm{GHGpc})$ & 1 & & & & & & & & & & & & & \\
\hline (2) $\ln ($ GDP) & 0.26 & 1 & & & & & & & & & & & & \\
\hline (3) PSAVT & 0.01 & 0.24 & 1 & & & & & & & & & & & \\
\hline (4) $\mathrm{CC}$ & 0.06 & 0.45 & 0.64 & 1 & & & & & & & & & & \\
\hline (5) GE & 0.07 & 0.49 & 0.59 & 0.90 & 1 & & & & & & & & & \\
\hline (6) $R Q$ & -0.16 & 0.22 & 0.51 & 0.79 & 0.86 & 1 & & & & & & & & \\
\hline (7) $\mathrm{RL}$ & 0.07 & 0.39 & 0.73 & 0.93 & 0.89 & 0.83 & 1 & & & & & & & \\
\hline (8) VA & 0.09 & 0.46 & 0.82 & 0.85 & 0.82 & 0.70 & 0.91 & 1 & & & & & & \\
\hline (9) ТЕCH & 0.04 & 0.10 & 0.27 & 0.25 & 0.25 & 0.21 & 0.29 & 0.37 & 1 & & & & & \\
\hline (10) EC & 0.06 & -0.72 & -0.31 & -0.59 & -0.65 & -0.53 & -0.55 & -0.59 & -0.23 & 1 & & & & \\
\hline (11) $\mathrm{EE}$ & -0.18 & -0.47 & 0.10 & -0.06 & -0.21 & 0.02 & -0.03 & -0.04 & 0.02 & 0.40 & 1 & & & \\
\hline (12) $\ln (\mathrm{P})$ & 0.23 & 0.37 & -0.38 & -0.04 & 0.08 & -0.02 & -0.15 & -0.18 & 0.04 & -0.31 & -0.42 & 1 & & \\
\hline (13) FDI & -0.06 & 0.07 & 0.32 & 0.33 & 0.38 & 0.44 & 0.43 & 0.37 & 0.13 & -0.12 & -0.08 & -0.22 & 1 & \\
\hline (14) TRADE & -0.30 & -0.29 & 0.15 & -0.13 & -0.15 & -0.08 & -0.06 & -0.04 & 0.07 & 0.39 & 0.30 & -0.50 & 0.26 & 1 \\
\hline
\end{tabular}

When including square and cubic terms of GDP and crossed products of GDP $\times$ INST and GDP $\times$ $\mathrm{TECH}$, it is possible to find multicollinearity problems among the explanatory variables. To detect these possible multicollinearity problems in the model, the variance inflation factor (VIF) is used. It is considered that the VIF value for each variable should not exceed the value 10 . When this happens, multicollinearity might not be a problem. Once the analysis is performed, values, much greater than 10, are found. To solve this problem, the solution provided by [25] and [26] was chosen. In keeping with these authors, the data were converted to deviations from the geometric mean of the sample. This is done to mitigate the multicollinearity problem. Once multicollinearity is tested again using the VIF values, none of them show values above 10. Consequently, square and cubic GDP terms are maintained within the specification model given in Equation (4). These same authors recommend that the presence of unit roots be researched, following [62]. The results show that variables are stationary in first-difference estimators by taking into account the previous tests. The data results were also transformed into first-difference estimators. Now, Equation (4) may be rewritten as

$$
\begin{aligned}
& \Delta \ln G H \bar{G} c_{i t}=\beta_{1} \Delta{\overline{\ln G D P p c_{i t}}}+\beta_{2} \Delta{\overline{\operatorname{lnGDPpc_{it}}}}^{2}+\beta_{3} \Delta{\overline{\ln G D P p c_{i t}}}^{3} \\
& +\beta_{4} \Delta \overline{I N S T_{i t}}+\beta_{5} \Delta \overline{T E C H}_{i t}+\beta_{6} \Delta\left(\overline{\operatorname{lnGDPpc_{it}}} \times \overline{I N S T_{i t}}\right) \\
& +\beta_{7} \Delta\left(\overline{\operatorname{lnGDPpc}} \times \overline{I N S T_{i t}}\right)^{2}
\end{aligned}
$$

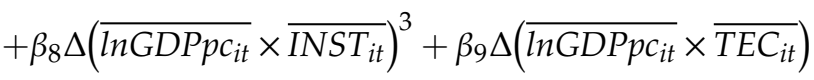

$$
\begin{aligned}
& +\beta_{10} \Delta(\overline{\operatorname{lnGDPpc} i t} \times \overline{\mathrm{TECH}})^{2}
\end{aligned}
$$

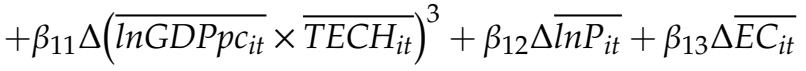

$$
\begin{aligned}
& +\beta_{14} \Delta \overline{E R M_{i t}}+\beta_{15} \Delta \overline{T R A D E_{i t}}+\beta_{16} \Delta \overline{F D I}+\mu_{i}+\delta_{t}+\varepsilon_{i t}
\end{aligned}
$$

The top bar in Equation (5) means deviations from the geometric mean. $\Delta$ indicates first-difference estimators.

To use the right specification for the model, it is essential to choose from among the pooled regression, the fixed-effects, and the random-effects models. To do this, the first step is to determine whether individual effects are relevant or not. If the individual effects are not relevant, the pooled regression model is the best option. In order to determine this, the Breusch-Pagan contrast [63] was performed. Contrast results suggest that the constant coefficient model was not suitable for the data. 
The second step is to choose between the fixed-effects and the random-effects models. The Hausman test provides an answer for the best choice $[64,65]$. The null hypothesis assumes that the most appropriate model is the random-effects, with the fixed-effects model being an alternative hypothesis. Test results rejected the null hypothesis, thus concluding that the best estimation technique for the data was provided by the model of fixed coefficients.

It was detected that panel data presents heteroscedasticity problems: Wald's test [66]; autocorrelation: Wooldridge AR test (1) [67]; contemporary correlation: Pesaran test [62]. To jointly solve these problems, estimations using the feasible generalized least squares method (FGLS) [68] were performed. The estimates included dummy variables for each year. STATA 13 statistical software was used.

\subsection{Discussion of Major Findings}

The available literature shows examples using square and cubic terms to estimate two different models. Here models are named as model 1 and model 2. Model 1 does not include cubic terms, while model 2 does. Table 5 contains results for model 1 from which cubic terms were excluded in the EKC analysis. Table 6 shows the results for model 2, where all variables considered were addressed. For each model, the results are offered for each of the six indicators, capturing the quality of institutions. Columns give information on indicators used. Indicator columns were used in each estimation. Standard errors are shown in parenthesis in Tables 5 and 6. Level of significance depends on the number of asterisks ( ${ }^{*}$ at $10 \%, * *$ at $5 \%$, and ${ }^{* * *}$ at $1 \%$ ).

Results support the EKC hypothesis for the sample of countries analyzed during 1996-2013. This answers our first research question. Coefficient values for per capita income show its elasticity value measured at the central point of the sample. In model 1, the signs for the linear GDPpc variable are positive and significant. Coefficients for the square term of the GDPpc variable are negative, passing the significance test at $1 \%$ for four of the six estimations made. As a result, the relationship between Greenhouse Gas emissions and income is well-represented by an inverted U curve. To analyze a possible relationship represented by an $\mathrm{N}$ form curve, model 2 included a cubic term for GDPpc. The results obtained show that all coefficients for the cubic term were negative and statistically significant in all estimations. These results do not prove that the trend reverses after a decrease in environmental stress.

Results go in line with [69] for a sample of eighteen Latin American and Caribbean countries for the period from 1980 to 2010. [15] also found significant evidence of an EKC relationship but focused on deforestation. However, controversy remains when compared with [25]. The results obtained in the estimations by these authors showed that the hypothesis postulated for the Energy-Environmental Kuznets Curve was not supported for the analyzed region. Controversy also appears when compared with [70]. They analyzed the relationship between economic growth and energy consumption for a sample of 21 Latin American and Caribbean countries. Their results did not support the existence of a stable long-term relationship between the series, and, as a consequence, the validity of such a hypothesis for the 1970-2007 period was rejected. Finally, [71] did not find a clear pattern related to the carbon dioxide emissions path when estimating EKC for a panel of 19 Latin-American and Caribbean countries over the period 1975-1998. Their results showed great heterogeneity between countries.

The analysis of the institutions' quality, together with the technological progress, constitutes a key issue in the novelty of this study. It is expected that both variables act as inhibitors of Greenhouse Gas emissions for the sample selected during the period under evaluation. The results offer the expected sign, both for model 1 and also for model 2. These results show negative signs for these two variable coefficients, thus passing the significance test at $1 \%$. This happens when using all the indicators to proxy the quality of institutions. The obtained results provide support for a negative relationship between the quality of the institutions and environmental stress. This implies that quality institutions promoted environmental sustainability across the 19-country sample. The only case in which a negative relationship was not found was when the Rule of Law (RL) was used to proxy the 
quality of institutions. In a more specific way, it could be said that the results obtained show that an increase of Political Stability and Absence of Violence/Terrorism (PSAVT), Control of Corruption (CC), Government Effectiveness (GE), Regulatory Quality (RQ), and Voice and Accountability (VA) will spark a decrease in Greenhouse Gas emissions. This gives an answer to our second research question, going in line with recommendations made by [69], when these authors wrote that to increase environmental protection, improvements in national law and regulations are essential. These authors also recommended that this be attained by creating a union between selected countries to establish a number of environmental acts to increase effectiveness on the pollution level. However, a decision must be made regarding available legal instruments for supporting international agreements (i.e., tradable emission permits vs. carbon taxes).

The results are also in line with the work of [14]. Focused on deforestation, these authors showed that institutional structure and macroeconomic policy affect the tropical deforestation process. As a consequence, improvements in political institutions significantly reduce deforestation. As in this paper, they also found strong evidence of an environmental Kuznets Curve (EKC) relationship between income and deforestation for all three continents. Results from [15] on the Latin American countries also showed the relevance of the institutional factors in reducing the rate of deforestation. Focused on China, [72,73] found evidence supporting the idea that local governments' intervention affects the relationship between industrial dynamics and environmental regulation.

The results for technological progress variables (TECH) also satisfy theoretical expectations, thus answering the third research question. The relationship observed between Greenhouse Gas emissions and technological progress is significantly negative at $1 \%$ for all of the estimations conducted.

According to the results obtained, the authors found robust evidence to show that both a higher level of institutional quality and a higher level of technological progress act as inhibitors of Greenhouse Gas emissions into the atmosphere.

The analysis conducted allowed this study to explore the interaction among GDPpc, an institution's quality indicators, and technological progress to demonstrate that the EKC approach is influenced by both types of variables. Results for model 1 show that the signs for the linear interaction coefficient of GDPpc are positive and significant in four of the six estimations. In the case of square term results for interaction coefficients, negative signs were seen in five of the six estimations. However, in this case, only PSAVT, GE, RL variables pass the significance test. Positive and significant coefficients in linear terms and negative and significant coefficients in square terms mean that in a first stage, environmental stress increases when the level of income and the quality of institutions increase until the maximum is reached. After reaching this maximum, an enhancement in the quality of institutions acts as an inhibitor of environmental stress caused by economic growth. Estimations of model 2 also offered positive signs for linear variables and negative signs for square and cubic variables. Once again, the results obtained show that upon reaching the maximum of the EKC, environmental stress decreases, while the trend is not reversed. Regarding interaction coefficients between GDPpc and technological progress, a U type graphical relationship was observed in model 2 (negative and significant signs in linear variables and positive and significant signs in square terms). The results for model 2 are less conclusive than for model 1. Estimations for the PSAVT, GE, and RL variables show a positive and significant relationship for linear and square variables, while coefficients for cubic variables show negative signs. When estimating $C C, R Q$, and VA, coefficients $\left(\beta_{9}\left\langle 0, \beta_{10}\right\rangle 0, \beta_{11}<0\right)$ are adjusted to an inverted $\mathrm{N}$ curve.

The results for control variables EC and ERM are as expected. Signs for coefficients of EC were positive and significant, thus showing that energy consumption acted as an important driver of Greenhouse Gas emissions. This is due to the fact that anthropogenic emissions from carbon dioxide are a primary result from the combustion of fossil fuels for energy uses, with energy consumption acting as a proxy for environmental stress. Coefficients for ERM were negative and significant, which verifies that an increase in the share of renewable energy sources makes Greenhouse Gas emissions decrease. Unfortunately, the results for variable P did not behave as expected. This is probably due to migration 
movements. Within the last decade, South America experienced significant changes in migration flows, with more movement within the region, mainly for work-related reasons. At the same time, a decline in emigration beyond the region was observed due to improved South American economies. Argentina, Brazil, and Chile have attracted the most significant amount of regional migration [74]. Increased flows of migrants moving across South America, particularly Venezuelans and Haitians, also appeared recently. Most Venezuelans have moved to Brazil, Colombia, Ecuador, or Peru, with Panama, Argentina, and Chile also receiving significant numbers of emigrants. Venezuelans, like most South Americans, need not have a visa to temporarily enter other countries in the region.

Finally, the results obtained for FDI and TRADE do not support the PHH. Here is the answer to our last research question. Results go in line with those provided in [75-77]. These authors found little evidence for the PHH. [78] found little evidence that pollution havens play a significant role in shaping the EKC for seven oft-studied pollutants. Our findings also go in line with [5], rejecting the $\mathrm{PHH}$ stance. [5] found that the polluting industries that tend to locate in less developed countries would also increase the income levels of the host country. Consequently, these host countries would also start to impose more stringent environmental regulations. The end of this process would occur when there is no country where polluting industries can relocate. All countries around the world would be on the same playing field. However, controversy in literature remains. Findings from [79] support the idea that FDI is positively related to pollution, which supports the pollution haven hypothesis for the 14 Latin American countries analyzed during the period from 1980 to 2010. Out of Latin American areas, and focusing on the Gulf Cooperation Council from 1990 to 2014, [80] found FDI inflows to have a negative impact on the environment.

Table 5. Model 1 results.

\begin{tabular}{|c|c|c|c|c|c|c|}
\hline & (1) PSAVT & (2) $\mathrm{CC}$ & (3) GE & (4) RQ & (5) RL & (6) VA \\
\hline \multirow[t]{2}{*}{$\begin{array}{c}\Delta \mathrm{LN} \\
(\mathrm{GDPPC})\end{array}$} & $0.344^{* * *}$ & $0.253^{* * *}$ & $0.138^{* * *}$ & $0.219^{* * *}$ & $0.172^{* * *}$ & $0.209^{* * *}$ \\
\hline & $(0.036)$ & $(0.052)$ & $(0.041)$ & $(0.031)$ & $(0.0140)$ & $(0.022)$ \\
\hline \multirow[t]{2}{*}{$\begin{array}{c}\Delta \mathrm{LN} \\
\left(G D P p c^{2}\right)\end{array}$} & $-0.124^{* * *}$ & $-0.091^{* * *}$ & -0.008 & -0.017 & $-0.082 * * *$ & $-0.082^{* * *}$ \\
\hline & $(0.031)$ & $(0.024)$ & $(0.022)$ & $(0.014)$ & $(0.0148)$ & (0.015) \\
\hline \multirow[t]{2}{*}{$\Delta \mathrm{LNST}$} & $-0.081^{* * *}$ & $-0.140^{* * *}$ & $-0.033^{* *}$ & $-0.042^{* * *}$ & $0.025^{* * *}$ & $-0.074^{* * *}$ \\
\hline & $(0.007)$ & $(0.011)$ & $(0.014)$ & $(0.010)$ & $(0.0026)$ & (0.009) \\
\hline \multirow[t]{2}{*}{$\triangle \mathrm{TECH}$} & $-0.002^{* * *}$ & $-0.001^{* * *}$ & $-0.003^{* * *}$ & $-0.002^{* * *}$ & $-0.002^{* * *}$ & $-0.002^{* * *}$ \\
\hline & $(0.000)$ & $(0.000)$ & $(0.000)$ & $(0.000)$ & $(0.0001)$ & $(0.000)$ \\
\hline \multirow[t]{2}{*}{$\begin{array}{l}\Delta \mathrm{LN} \text { (GDP) } \\
\quad{ }^{*} \text { INST }\end{array}$} & $0.039^{* *}$ & $0.074^{* * *}$ & $-0.126^{* * *}$ & $-0.096^{* * *}$ & $0.076^{* * *}$ & $0.221^{* * *}$ \\
\hline & $(0.018)$ & $(0.019)$ & $(0.022)$ & $(0.018)$ & $(0.0090)$ & $(0.014)$ \\
\hline \multirow[t]{2}{*}{$\begin{array}{c}\Delta \mathrm{LN}\left(G D P^{2}\right) \\
\quad \text { INST }\end{array}$} & $-0.084^{* * *}$ & -0.012 & $-0.048^{* *}$ & $0.093^{* * *}$ & $-0.043^{* * *}$ & -0.008 \\
\hline & $(0.022)$ & $(0.023)$ & $(0.022)$ & $(0.022)$ & $(0.0098)$ & $(0.021)$ \\
\hline \multirow[t]{2}{*}{$\begin{array}{l}\Delta \mathrm{LN}(\mathrm{GDP}) \\
{ }^{*} \mathrm{TECH}\end{array}$} & $-0.003^{* * *}$ & $-0.004^{* * *}$ & $-0.004^{* * *}$ & $-0.003^{* * *}$ & $-0.003^{* * *}$ & $-0.004^{* * *}$ \\
\hline & $(0.001)$ & $(0.001)$ & $(0.001)$ & $(0.001)$ & $(0.0004)$ & $(0.001)$ \\
\hline \multirow[t]{2}{*}{$\begin{array}{c}\Delta \mathrm{LN}\left(G D P^{2}\right) \\
{ }^{*} \mathrm{TECH}\end{array}$} & $0.010^{* * *}$ & $0.009^{* * *}$ & $0.010 * * *$ & $0.009 * * *$ & $0.010^{* * *}$ & $0.011^{* * *}$ \\
\hline & $(0.001)$ & $(0.002)$ & $(0.001)$ & $(0.001)$ & $(0.0005)$ & $(0.001)$ \\
\hline
\end{tabular}


Table 5. Cont.

\begin{tabular}{|c|c|c|c|c|c|c|}
\hline & (1) PSAVT & (2) $\mathrm{CC}$ & (3) GE & (4) $R Q$ & (5) $\mathrm{RL}$ & (6) VA \\
\hline \multirow[t]{2}{*}{$\Delta \mathrm{EC}$} & $0.068^{* * *}$ & $0.072 * * *$ & $0.098^{* * *}$ & $0.063^{* * *}$ & $0.074^{* * *}$ & $0.075^{* * *}$ \\
\hline & $(0.018)$ & $(0.020)$ & $(0.014)$ & $(0.018)$ & $(0.0045)$ & $(0.013)$ \\
\hline \multirow[t]{2}{*}{$\Delta \mathrm{EE}$} & $-0.004^{* * *}$ & $-0.005^{* * *}$ & $-0.005^{* * *}$ & $-0.005^{* * *}$ & $-0.005^{* * *}$ & $-0.005^{* * *}$ \\
\hline & $(0.000)$ & $(0.000)$ & $(0.000)$ & $(0.000)$ & $(0.0001)$ & $(0.000)$ \\
\hline \multirow[t]{2}{*}{$\Delta \mathrm{LN}(\mathrm{P})$} & $-0.384^{* *}$ & -0.057 & $-0.461^{* * *}$ & $-0.586^{* * *}$ & 0.018 & -0.177 \\
\hline & $(0.158)$ & $(0.253)$ & (0.095) & $(0.112)$ & $(0.0786)$ & $(0.125)$ \\
\hline \multirow[t]{2}{*}{$\Delta$ FDI } & $-0.009 * * *$ & $-0.010^{* * *}$ & $-0.010^{* * *}$ & $-0.010 * * *$ & $-0.011^{* * *}$ & $-0.009 * * *$ \\
\hline & $(0.001)$ & $(0.000)$ & $(0.000)$ & $(0.001)$ & $(0.0002)$ & $(0.000)$ \\
\hline \multirow[t]{2}{*}{$\Delta \mathrm{TRADE}$} & $-0.001^{* * *}$ & $-0.001^{* * *}$ & $-0.001^{* * *}$ & $-0.002^{* * *}$ & $-0.001^{* * *}$ & $-0.001^{* * *}$ \\
\hline & $(0.000)$ & $(0.000)$ & $(0.000)$ & $(0.000)$ & $(0.0001)$ & $(0.000)$ \\
\hline $\begin{array}{l}\text { WALD } \\
\text { CHI2(30) }\end{array}$ & $2,854,429$ & $1,545,303$ & $4,573,330$ & $2,857,421$ & $75,600,000$ & $429,000,000$ \\
\hline PROB > CHI2 & 0.0000 & 0.0000 & 0.0000 & 0.0000 & 0.0000 & 0.0000 \\
\hline OBS & 306 & 306 & 306 & 306 & 306 & 306 \\
\hline
\end{tabular}

NOTE: STANDARD ERRORS ARE SHOWN IN PARENTHESIS. THE ESTIMATES CONTAIN DUMMIES FOR EACH YEAR. * INDICATES SIGNIFICANCE AT 10\%. ** INDICATES SIGNIFICANCE AT 5\%. *** INDICATES SIGNIFICANCE AT 1\%.

Table 6. Model 2 results.

\begin{tabular}{|c|c|c|c|c|c|c|}
\hline & (1) PSAVT & (2) CC & (3) GE & (4) $R Q$ & (5) $\mathrm{RL}$ & (6) VA \\
\hline \multirow[t]{2}{*}{$\begin{array}{c}\Delta \mathrm{LN} \\
\text { (GDPPC) }\end{array}$} & $0.406^{* * *}$ & $0.370^{* * *}$ & $0.256^{* * *}$ & $0.318^{* * *}$ & $0.263^{* * *}$ & $0.393^{* * *}$ \\
\hline & $(0.038)$ & $(0.069)$ & $(0.042)$ & $(0.042)$ & $(0.048)$ & $(0.053)$ \\
\hline \multirow[t]{2}{*}{$\begin{array}{c}\Delta \mathrm{LN} \\
\left(G D P p c^{2}\right)\end{array}$} & $-0.126^{* * *}$ & 0.006 & -0.007 & 0.018 & -0.025 & 0.006 \\
\hline & $(0.030)$ & $(0.036)$ & $(0.030)$ & (0.029) & $(0.030)$ & (0.035) \\
\hline \multirow[t]{2}{*}{$\begin{array}{c}\Delta \mathrm{LN} \\
\left(G D P p c^{3}\right)\end{array}$} & $-0.231^{* * *}$ & $-0.178^{* * *}$ & $-0.140^{* * *}$ & $-0.154^{* * *}$ & $-0.133^{* * *}$ & $-0.162^{* * *}$ \\
\hline & $(0.040)$ & $(0.043)$ & $(0.029)$ & $(0.030)$ & (0.039) & $(0.037)$ \\
\hline \multirow[t]{2}{*}{$\Delta \mathrm{LNST}$} & $-0.107^{* * *}$ & $-0.130^{* * *}$ & $-0.056^{* * *}$ & $-0.053^{* * *}$ & 0.007 & $-0.131^{* * *}$ \\
\hline & $(0.008)$ & $(0.019)$ & (0.013) & $(0.012)$ & (0.013) & (0.023) \\
\hline \multirow[t]{2}{*}{$\triangle \mathrm{TECH}$} & $-0.001^{* * *}$ & -0.001 & $-0.002^{* * *}$ & $-0.002^{* * *}$ & $-0.002^{* * *}$ & $-0.002^{* *}$ \\
\hline & $(0.000)$ & $(0.001)$ & $(0.001)$ & $(0.000)$ & $(0.000)$ & $(0.001)$ \\
\hline \multirow[t]{2}{*}{$\begin{array}{l}\Delta \mathrm{LN}(\mathrm{GDP}) \\
\quad{ }^{\mathrm{T}} \mathrm{TECH}\end{array}$} & $0.061^{* * *}$ & 0.185 & $-0.165^{* * *}$ & $-0.053^{* * *}$ & 0.036 & $0.540 * * *$ \\
\hline & $(0.018)$ & $(0.034)$ & $(0.026)$ & $(0.024)$ & (0.033) & (0.046) \\
\hline \multirow[t]{2}{*}{$\begin{array}{c}\Delta \mathrm{LN}\left(G D P^{2}\right) \\
\text { *INST }\end{array}$} & $-0.072^{* * *}$ & $0.060^{* * *}$ & -0.006 & $0.141^{* * *}$ & 0.000 & $0.156^{* * *}$ \\
\hline & $(0.018)$ & $(0.028)$ & $(0.024)$ & $(0.025)$ & $(0.021)$ & $(0.040)$ \\
\hline \multirow[t]{2}{*}{$\begin{array}{c}\Delta \mathrm{LN}\left(G D P^{3}\right) \\
\quad * \text { INST }\end{array}$} & $-0.063^{* *}$ & -0.111 & 0.057 * & $-0.078^{* * *}$ & -0.005 & $-0.591^{* * *}$ \\
\hline & $(0.028)$ & $(0.036)$ & $(0.034)$ & $(0.032)$ & $(0.034)$ & $(0.057)$ \\
\hline
\end{tabular}


Table 6. Cont.

\begin{tabular}{|c|c|c|c|c|c|c|}
\hline & (1) PSAVT & (2) CC & (3) GE & (4) RQ & (5) RL & (6) VA \\
\hline \multirow[t]{2}{*}{$\begin{array}{c}\Delta \mathrm{LN}(\mathrm{GDP}) \\
* \mathrm{TECH}\end{array}$} & $0.010^{* * *}$ & $-0.002^{* * *}$ & $0.005^{* * *}$ & -0.001 & 0.002 & -0.002 \\
\hline & $(0.001)$ & $(0.003)$ & $(0.002)$ & $(0.002)$ & $(0.002)$ & $(0.003)$ \\
\hline \multirow[t]{2}{*}{$\begin{array}{c}\Delta \mathrm{LN}\left(G D P^{2}\right) \\
* \text { TECH }\end{array}$} & $0.007^{* * *}$ & $0.007^{* * *}$ & $0.008^{* * *}$ & $0.008^{* * *}$ & $0.009^{* * *}$ & $0.009^{* * *}$ \\
\hline & $(0.001)$ & $(0.002)$ & $(0.001)$ & $(0.001)$ & $(0.001)$ & $(0.002)$ \\
\hline \multirow[t]{2}{*}{$\begin{array}{c}\Delta \mathrm{LN}\left(G D P^{3}\right) \\
* \mathrm{TECH}\end{array}$} & $-0.019 * * *$ & $-0.002^{* * *}$ & $-0.013^{* * *}$ & -0.004 & $-0.010^{* * *}$ & -0.006 \\
\hline & $(0.002)$ & $(0.004)$ & $(0.003)$ & (0.003) & (0.003) & $(0.004)$ \\
\hline \multirow[t]{2}{*}{$\Delta \mathrm{EC}$} & $0.037^{* *}$ & $0.060 * * *$ & $0.092 * * *$ & $0.055^{* * *}$ & $0.072 * * *$ & $0.056^{* * *}$ \\
\hline & $(0.018)$ & $(0.026)$ & $(0.013)$ & $(0.014)$ & $(0.014)$ & $(0.020)$ \\
\hline \multirow[t]{2}{*}{$\Delta \mathrm{EE}$} & $-0.005^{* * *}$ & $-0.005^{* * *}$ & $-0.005^{* * *}$ & $-0.004^{* * *}$ & $-0.004^{* * *}$ & $-0.004^{* * *}$ \\
\hline & $(0.000)$ & $(0.001)$ & $(0.000)$ & $(0.000)$ & $(0.000)$ & $(0.001)$ \\
\hline \multirow[t]{2}{*}{$\Delta \mathrm{LN}(\mathrm{P})$} & $-0.449 * * *$ & $-0.404^{* * *}$ & $-0.668^{* * *}$ & $-1.088^{* * *}$ & -0.725 * & -0.658 \\
\hline & $(0.137)$ & $(0.223)$ & $(0.149)$ & $(0.320)$ & $(0.391)$ & $(0.558)$ \\
\hline \multirow[t]{2}{*}{$\Delta$ FDI } & $-0.009 * * *$ & $-0.009^{* * *}$ & $-0.010^{* * *}$ & $-0.010^{* * *}$ & $-0.010^{* * *}$ & $-0.007^{* * *}$ \\
\hline & $(0.000)$ & $(0.001)$ & $(0.000)$ & $(0.001)$ & $(0.001)$ & $(0.001)$ \\
\hline \multirow[t]{2}{*}{$\Delta$ TRADE } & $-0.002^{* * *}$ & $-0.001^{* * *}$ & $-0.001^{* * *}$ & $-0.001^{* * *}$ & $-0.001^{* * *}$ & $-0.001^{* * *}$ \\
\hline & $(0.000)$ & $(0.000)$ & $(0.000)$ & $(0.000)$ & $(0.000)$ & $(0.000)$ \\
\hline $\begin{array}{c}\text { WALD } \\
\text { CHI2(33) }\end{array}$ & $5,526,160$ & $169,000,000$ & $1,210,087$ & $6,954,258$ & $4,969,125$ & $9,365,484$ \\
\hline PROB > CHI2 & 0.0000 & 0.0000 & 0.0000 & 0.0000 & 0.0000 & 0.0000 \\
\hline OBS & 306 & 306 & 306 & 306 & 306 & 306 \\
\hline
\end{tabular}

NOTE: STANDARD ERRORS ARE SHOWN IN PARENTHESIS. THE ESTIMATES CONTAIN DUMMIES FOR EACH YEAR. * INDICATES SIGNIFICANCE AT 10\%. ${ }^{* *}$ INDICATES SIGNIFICANCE AT 5\%. ${ }^{* * *}$ INDICATES SIGNIFICANCE AT $1 \%$.

\section{Conclusions}

By using a panel of eighteen countries from Latin America for the period 1996-2013, based on the Environmental Kuznets Curve hypothesis, this article mainly re-examines not only the Pollution Haven Hypothesis and the relationship between environmental degradation and economic growth but also the role played by the quality of institutions and technological progress on environmental stress. The results show that the relationship between income and Greenhouse Gas emissions adjusts to the traditional Environmental Kuznets Curve EKC hypothesis, and the quality of institutions and technological progress has a significant negative effect on the relationship between quality of institutions and environmental stress.

For the eighteen Latin American countries selected, the results obtained allow us to conclude that the relationship between income and Greenhouse Gas emissions adjusts to the traditional EKC hypothesis for the period 1996-2013. This is an affirmative answer to the first research question: Did Latin American Greenhouse Gas emissions prove the EKC hypothesis? This tells us that from the sustainability perspective, reaching the maximum EKC point sooner becomes a crucial point. The results also show negative and significant signs for cubic terms in all of the conducted estimations. Consequently, it does not prove that the trend reverses after a decrease in environmental stress.

These results support the theory that any increase in Political Stability and Absence of Violence/Terrorism (PSAVT), Control of Corruption (CC), Government Effectiveness (GE), Regulatory 
Quality (RQ), Rule of Law (RL), and Voice and Accountability (VA) causes a decrease in Greenhouse Gas emissions. Such results give a positive answer to the research question: Did the quality of institutions play a compensating role for income on environmental stress? This study concludes that the quality of institutions helps to move towards sustainable production models. Political measures oriented towards enhancing the quality of institutions would soften EKC, thus making it easier to reach the maximum. The quality of institutions' improvement, mainly those of a legal nature, should preferably be based on an international perspective since environmental degradation is a clear example of a negative externality.

The results for technological progress also satisfy theoretical expectations, so a positive answer is given to the third research question: Did technological progress act in line with the quality of institutions to help decouple income from environmental stress? As a conclusion and in line with the arguments given above, technological progress facilitates reaching EKC's maximum faster and, therefore, contributes to sustainability. Political measures oriented towards increasing Research and Development must be promoted.

Regarding the control variables for energy consumption (EC) and energy matrix (ERM), their behavior was as expected. The energy consumption variable coefficients were positive and significant. This result shows that the energy consumption acted as an important driver of Greenhouse Gas emissions opposite to a transition to better levels of sustainability. Signs of variable ERM coefficients were negative and statistically significant, thus verifying that an increase in the share of renewable energy sources used reduces Greenhouse Gas emissions. In terms of the results for the variables, Foreign Direct Investment (FDI) and International Trade (TRADE), these provided a negative answer to our last question: Has the Pollution Haven Hypothesis been proven for the selected sample during the period under consideration?

During the period under analysis, important international agreements were put in place to fight against Climate Change. The most important agreements were the Montreal Protocol (1989), the Kyoto Protocol (1998), and the Copenhagen Accord (2009) on global warming. Although the countries in the sample have the status of non-Annex I countries, that is, they did not assume mandatory commitments to mitigate Greenhouse Gas emissions, this did not prevent them from strengthening their legal framework to protect the environment by diverting the most polluting investments to other countries with less demanding legislation. In this sense, the legislative changes moved in the right direction.

Author Contributions: J.M.C. conceived the idea, discussed the obtained results, and co-authorized the manuscript. R.R.-C. co-authorized the manuscript and wrote conclusions. J.C.M. expanded the classic EKC model, ran models, obtained results, and co-authorized the manuscript.

Funding: This research received no external funding.

Acknowledgments: The authors wish to acknowledge the funding provided by the following institutions: the Andalusian Regional Government (project SEJ-132), the "Cátedra de Economía de la Energía y del Medio Ambiente" sponsored by Red Eléctrica de España at the University of Seville," and from Departamento de Análisis Económico y Economía Política (Department of Economic Analysis and Political Economy (Universidad de Sevilla) at the University of Seville. The first and second authors also acknowledge the funding provided by the Universidad Autónoma de Chile (Chile).

Conflicts of Interest: The authors declare no conflict of interest.

\section{References}

1. Kuznets, S. Economic Growth and Income Inequality. Am. Econ. Assoc. 1955, 45, 1-28.

2. Grossman, G.M.; Krueger, A.B. Economic Growth and the Environment. Q. J. Econ. 1995, 110, $353-377$. [CrossRef]

3. Panayotou, T. Economic growth and the environment. In The environment in Anthropoly; Haenn, N., Wilck, R.R., Eds.; NYU Press: New York, NY, USA, 2016; pp. 140-148.

4. Yandle, B.; Vijayaraghavan, M.; Bhattarai, M. The Environmental Kuznets Curve; A Primer, PERC Research Study; The Property and Environment Research Center: Bozeman, MT, USA, 2002.

5. Dinda, S. Environmental Kuznets Curve Hypothesis: A Survey. Ecol. Econ. 2004, 49, 431-455. [CrossRef] 
6. Kaika, D.; Zervas, E. The Environmental Kuznets Curve (EKC) theory-Part A: Concept, causes and the $\mathrm{CO}_{2}$ emissions case. Energy Policy 2013, 62, 1392-1402. [CrossRef]

7. Stern, D.I. The rise and fall of the environmental Kuznets curve. World Dev. 2004, 32, 1419-1439. [CrossRef]

8. Panayotou, T. Demystifying the environmental Kuznets curve: Turning a black box into a policy tool. Environ. Dev. Econ. 1997, 2, 465-484. [CrossRef]

9. Munasinghe, M. Is environmental degradation an inevitable consequence of economic growth: Tunneling through the environmental Kuznets curve. Ecol. Econ. 1999, 29, 89-109. [CrossRef]

10. North, D.C. Institutions. J. Econ. Perspect. 1991, 5, 97-112. [CrossRef]

11. OECD-Organization for Economic Co-Operation and Development 2002. Indicators to Measure Decoupling of Environmental Pressure from Economic Growth Sustainable Development. SG/SD (2002) 1/Final (2002). Available online: http://www.olis.oecd.org/olis/2002doc.nsf/LinkTo/sg-sd(2002)1-final (accessed on 25 October 2018).

12. De Freitas, L.C.; Kaneko, S. Decomposing the decoupling of $\mathrm{CO}_{2}$ emissions and economic growth in Brazil. Ecol. Econ. 2011, 70, 1459-1469. [CrossRef]

13. Mundaca, L. Climate change and energy policy in Chile: Up in smoke? Energy Policy 2013, 52, $235-248$. [CrossRef]

14. Bhattarai, M.; Hammig, M. Institutions and the Environmental Kuznets Curve for Deforestation: A Crosscountry Analysis for Latin America, Africa and Asia. World Dev. 2001, 29, 995-1010. [CrossRef]

15. Culas, R.J. Deforestation and the environmental Kuznets curve: An institutional perspective. Ecol. Econ. 2007, 61, 429-437. [CrossRef]

16. Bernauer, T.; Koubi, V. Effects of political institutions on air quality. Ecol. Econ. 2009, 68, 1355-1365. [CrossRef]

17. Bhattacharya, M.; Awaworyi, C.S.; Paramati, S.R. The dynamic impact of renewable energy and institutions on economic output and $\mathrm{CO}_{2}$ emissions across regions. Renew. Energy 2017, 111, 157-167. [CrossRef]

18. Hosseini, M.H.; Kaneko, S. Can environmental quality spread through institutions? Energy Policy 2013, 56, 312-321. [CrossRef]

19. Bokpin, G.A. Foreign direct investment and environmental sustainability in Africa: The role of institutions and governance. Res. Int. Bus. Finance 2017, 39, 239-247. [CrossRef]

20. Gill, F.L.; Viswanathan, K.K.; Karim, M.Z.A. The Critical Review of the Pollution Haven Hypothesis (PHH). Int. J. Energy Econ. Policy 2018, 8, 167-174.

21. Leamer, E.E. Sources of International Comparative Advantage: Theory and Evidence; MIT press: Cambridge, MA, USA, 1984.

22. Cole, M.A.; Elliott, R.J. FDI and the capital intensity of "dirty" sectors: A missing piece of the pollution haven puzzle. Rev. Dev. Econ. 2005, 9, 530-548. [CrossRef]

23. Mabey, N.; McNally, R. Foreign Direct Investment and the Environment: from Pollution Havens to Sustainable Development; A WWF-UK Report; World Wildlife Fund: London. UK, 1999.

24. De Bruyn, S. Explaining the environmental Kuznets curve: Structural change and international agreements in reducing sulphur emissions. Environ. Dev. Econ. 1997, 2, 485-503. [CrossRef]

25. Pablo-Romero, M.d.P.; De Jesús, J. Economic growth and energy consumption: The Energy-Environmental Kuznets Curve for Latin America and the Caribbean. Renew. Sustain. Energy Rev. 2016, 60, 1343-1350. [CrossRef]

26. Pablo-Romero, M.d.P.; Sánchez-Braza, A. Residential energy environmental Kuznets curve in the EU-28. Energy 2017, 125, 44-54. [CrossRef]

27. Özokcu, S.; Özdemir, Ö. Economic growth, energy, and environmental Kuznets curve. Renew. Sustain. Energy Rev. 2017, 72, 639-647. [CrossRef]

28. Liobikienè, G.; Butkus, M. Environmental Kuznets Curve of greenhouse gas emissions including technological progress and substitution effects. Energy 2017, 135, 237-248. [CrossRef]

29. Sanchez, L.F.; Stern, D.I. Drivers of industrial and non-industrial greenhouse gas emissions. Ecol. Econ. 2016, 124, 17-24. [CrossRef]

30. Yang, X.; Lou, F.; Sun, M.; Wang, R.; Wang, Y. Study of the relationship between greenhouse gas emissions and the economic growth of Russia based on the Environmental Kuznets Curve. Appl. Energy 2017, 193, 162-173. [CrossRef]

31. Lu, W.C. Greenhouse gas emissions, energy consumption and economic growth: A panel cointegration analysis for 16 Asian countries. Int. J. Environ. Res. Public Health 2017, 14, 1436. [CrossRef] 
32. Yin, J.; Zheng, M.; Chen, J. The effects of environmental regulation and technical progress on $\mathrm{CO}_{2} \mathrm{Kuznets}$ curve: An evidence from China. Energy Policy 2015, 77, 97-108. [CrossRef]

33. Apergis, N.; Ozturk, I. Testing environmental Kuznets Curve hypothesis in Asian countries. Ecol. Indic. 2015, 52, 16-22. [CrossRef]

34. Chang, C.P.; Hao, Y. Environmental performance, corruption and economic growth: Global evidence using a new data set. Appl. Econ. 2016, 49, 498-514. [CrossRef]

35. Halkos, G.E.; Paizanos, E.A. The channels of the effect of government expenditure on the environment: Evidence using dynamic panel data. J. Environ. Plan. Manag. 2017, 60, 135-157. [CrossRef]

36. Charfeddine, L.; Mrabet, Z. The impact of economic development and social-political factors on ecological footprint: A panel data analysis for 15 MENA countries. Renew. Sustain. Energy Rev. 2017, 76, 138-154. [CrossRef]

37. WGI, The World Bank Group. Available online: http://info.worldbank.org/governance/wgi/\#reports (accessed on 15 June 2017).

38. Kaufmann, D.; Kraay, A.; Mastruzzi, M. Response to 'What do the worldwide governance indicators measure?'. Eur. J. Dev. Res. 2010, 22, 55-58. [CrossRef]

39. Cole, M.A. Trade, the pollution haven hypothesis and the environmental Kuznets curve: Examining the linkages. Ecol. Econ. 2004, 48, 71-81. [CrossRef]

40. Ehrlich, P.R.; Holdren, J.P. Impact of Population Growth. Science 1971, 171, 1212-1217. [CrossRef] [PubMed]

41. Commoner, B. The Closing Circle: Nature, Man, and Technology; Alfred A. Knopf: New York, NY, USA, 1971.

42. Dietz, T.; Rosa, A.E. Rethinking the Environmental Impacts of Population, Affluence and Technology. Hum. Ecol. Rev. 1994, 1, 277-300.

43. Dietz, T.; Rosa, A.E. Climate change and society: Speculation, construction and scientific investigation. Int. Sociol. 1998, 13, 421-455.

44. Wernick, I.K.; Waggoner, P.E.; Ausubel, J.H. Searching for Leverage to Conserve Forests: The Industrial Ecology of Wood Products in the United States. J. Ind. Ecol. 1997, 1, 125-145. [CrossRef]

45. Grossman, G.M.; Krueger, A.B. Environmental Impacts of a North American Free Trade Agreement; The Mexico-U.S. Free Trade Agreement, Garber, P., Eds.; MIT Press: Cambridge, MA, USA, 1993.

46. Copeland, B.R.; Taylor, M.S. Trade, growth, and the environment. J. Econ. Lit. 2004, 42, 7-71. [CrossRef]

47. Zhang, S.; Liu, X.; Bae, J. Does trade openness affect $\mathrm{CO}_{2}$ emissions: Evidence from ten newly industrialized countries? Environ. Sci. Pollut. Res. 2017, 24, 17616-17625. [CrossRef]

48. Ozatac, N.; Gokmenoglu, K.K.; Taspinar, N. Testing the EKC hypothesis by considering trade openness, urbanization, and financial development: The case of Turkey. Environ. Sci. Pollut. Res. 2017, 24, 16690-16701. [CrossRef]

49. López, L.A.; Arce, G.; Zafrilla, J.E. Parcelling virtual carbon in the pollution haven hypothesis. Energy Econ. 2013, 39, 177-186. [CrossRef]

50. Xing, Y.; Kolstad, C.D. Do Lax Environmental Regulations Attract Foreign Investment? Environ. Res. Econ. 2002, 21, 1-22. [CrossRef]

51. He, J. Pollution haven hypothesis and environmental impacts of foreign direct investment: The case of industrial emission of sulfur dioxide $\left(\mathrm{SO}_{2}\right)$ in Chinese provinces. Ecol. Econ. 2006, 60, 228-245. [CrossRef]

52. Mulatu, A. The Structure of UK Outbound FDI and Environmental Regulation. Environ. Resour. Econ. 2017, 68, 65-96. [CrossRef]

53. Sun, C.; Zhang, F.; Xu, M. Investigation of pollution haven hypothesis for China: An ARDL approach with breakpoint unit root tests. J. Clean. Prod. 2017, 161, 153-164. [CrossRef]

54. Liu, Y.; Hao, Y.; Gao, Y. The environmental consequences of domestic and foreign investment: Evidence from China. Energy Policy 2017, 108, 271-280. [CrossRef]

55. Forslid, R.; Okubo, T.; Sanctuary, M. Trade Liberalization, Transboundary Pollution, and Market Size. J. Assoc. Environ. Resour. Econ. 2017, 4, 927-957. [CrossRef]

56. Hoffman, R.; Sing, L.C.; Ramasamy, B.; Yeung, M. FDI and pollution: A granger causality test using panel data. J. Int. Dev. 2005, 17, 311-317. [CrossRef]

57. Kentor, J.; Boswell, T. Foreign capital dependence and development: A new direction. Am. Sociol. Rev. 2003, 68, 301-313. [CrossRef] 
58. Jorgenson, A.K. Does foreign investment harm the air we breathe and the water we drink? A cross-national study of carbon dioxide emissions and organic water pollution in less-developed countries 1975-2000. Organ. Environ. 2007, 20, 137-156. [CrossRef]

59. Jorgenson, A.K. Foreign direct investment and the environment, the mitigating influence of institutional and civil society factors, and relationship between industrial pollution and human health: A panel study of less-developed countries. Organ. Environ. 2009, 22, 135-157. [CrossRef]

60. Jorgenson, A.K. The transnational organization of production, the scale of degradation: And eco efficiency: A study of carbon dioxide emissions in less-developed countries. Hum. Ecol. Rev. 2009, 16, 64-74.

61. Kanemoto, K.; Moran, D.; Lenzen, M.; Geschke, A. International trade undermines national emission reduction targets: New evidence from air pollution. Glob. Environ. Chang. 2014, 24, 52-59. [CrossRef]

62. Pesaran, M.H. General Diagnostic Tests for Cross Section Dependence in Panels; Cambridge Working Papers WP0435; Faculty of Economics University of Cambridge: Cambridge, UK, 2004.

63. Breusch, T.; Pagan, A. The Lagrange multiplier and its applications to model specificatión in econometrics. Rev. Econ. Stud. 1980, 47, 239-253. [CrossRef]

64. Hausman, J.A. Specification test in econometrics. Econometrica 1978, 46, 1251-1271. [CrossRef]

65. Hausman, J.; McFadden, C. Specification test in econometrics. Econometrica 1984, 52, 1219-1240. [CrossRef]

66. Greene, W.H. Econometric Analysis, 7th ed.; Stern School of Business New York University: Pearson, London, UK, 2012.

67. Wooldridge, J. Econometric Analysis of Cross Section and Panel Data; MIT Press: Cambridge, MA, USA, 2002.

68. Beck, N. Time-Series-Cross-Section Data: What have we learned in the past few years? Ann. Rev. Polit. Sci. 2001, 4, 271-293. [CrossRef]

69. Al-Mulali, U.; Tang, C.F.; Ozturk, I. Estimating the environment Kuznets curve hypothesis: Evidence from Latin America and the Caribbean countries. Renew. Sustain. Energy Rev. 2015, 50, 918-924. [CrossRef]

70. Zilio, M.; Recalde, M. GDP and environment pressure: The role of energy in Latin America and the Caribbean. Energy Policy 2011, 39, 7941-7949. [CrossRef]

71. Martinez-Zarzoso, I.; Bengochea, A. Testing for an Environmental Kuznets Curve in Latin-American Countries. Rev. Anal. Econ. 2003, 18, 2003.

72. Zhou, Y.; Zhu, S.; He, C. How do environmental regulations affect industrial dynamics? Evidence from China's pollution-intensive industries. Habitat Int. 2017, 60, 10-18. [CrossRef]

73. Shen, J.; Wei, Y.D.; Yang, Z. The impact of environmental regulations on the location of pollution-intensive industries in China. J. Clean. Prod. 2017, 148, 785-794. [CrossRef]

74. Migration Policy Institute, n.d. Available online: https://www.migrationpolicy.org/regions/south-america (accessed on 22 October 2018).

75. Smarzynska, B.; Wei, S.J. Pollution Havens and Foreign Direct Investment: Dirty Secret or Popular Myth? Working Papers 8465; National Bureau of Economic Research: Cambridge, MA, USA, 2005.

76. Eskeland, G.; Harrison, A. Moving to greener pastures? Multinationals and the pollution-haven hypothesis. J. Dev. Econ. 2003, 70, 1-23. [CrossRef]

77. Dean, J.M.; Lovely, M.E.; Wang, H. Foreign Direct Investment and Pollution Havens: Evaluating the Evidence from China; Working Paper N²004-01-B U.S. International Trade Commission: Washington, DC, USA, 2002.

78. Kearsley, A.; Riddel, M. A further inquiry into the Pollution Haven Hypothesis and the Environmental Kuznets Curve. Ecol. Econ. 2010, 69, 905-919. [CrossRef]

79. Sapkota, P.; Bastola, U. Foreign direct investment, income, and environmental pollution in developing countries: Panel data analysis of Latin America. Energy Econ. 2017, 64, 206-212. [CrossRef]

80. Rafindadi, A.A.; Muye, I.M.; Kaita, R.A. The effects of FDI and energy consumption on environmental pollution in predominantly resource-based economies of the GCC. Sustain. Energy Technol. Assess. 2018, 25, 126-137. [CrossRef]

(C) 2019 by the authors. Licensee MDPI, Basel, Switzerland. This article is an open access article distributed under the terms and conditions of the Creative Commons Attribution (CC BY) license (http://creativecommons.org/licenses/by/4.0/). 